\title{
STANDARDS FOR STATE-BUILDING INTERVENTIONS
}

\author{
Roger B. Myerson, March 2012 \\ http://home.uchicago.edu/ rmyerson/research/std4sb.pdf
}

Abstract. This paper considers the question of defining standards for democratic state-building. One may question the possibility of benevolent state-building interventions, but any hope for planning such interventions, or for holding their planners to account, requires some understanding of what should come first in building a successful democratic society. Elections are not enough. Successful democratic development depends on a plentiful supply of leaders who have good reputations for using public funds responsibly in both local and national politics. I argue that, if the goal of an intervention is truly to help establish a sovereign democratic state, not to install a hand-picked leadership dependent on foreign support, then interveners should foster a political reconstruction based on elected local councils and a national assembly, with parliamentary responsibility for local and national administration.

\section{Introduction}

When we live in a successful democratic society, we are surrounded by political, legal, economic, and social institutions, each of which seems to depend on many of the others. When these institutions do not exist or are not functioning, which institutions must be established first to begin moving from anarchy toward prosperity? This is one of the great questions of social science. In state-building emergencies after the breakdown of a state, such theoretical questions about the foundations of the state become practical policy concerns. (See The Beginner's Guide to Nation-Building by James Dobbins and co-authors, 2007.) One may question the very possibility of benevolent state-building interventions by foreign powers, but any hope for planning such interventions, or for holding their planners to account, requires us to have some understanding of what should come first in building a successful democratic society.

This essay considers basic questions about the foundations of the state from the practical perspective of situations where foreign powers have intervened militarily in a nation with an announced intention to reconstruct its political system as an independent democratic state. To focus the discussion, I will try to develop some general guidelines for occupying powers in such state-building interventions. In The Bottom Billion (2007), Paul Collier argued that the developed world can help poor nations by formulating various "charters" that define standards of international policies to promote a variety of important objectives, from transparent accounting of poor countries' natural resource revenues to post-conflict reconciliation. In this paper I want to consider a charter for custodians of democratic state-building. I will argue that, in such 
situations, the occupying powers should, with the broadest possible multinational support, foster a political reconstruction based on two pillars: a national assembly and elected local councils, because democratic development ultimately depends on a plentiful supply of leaders who have good reputations for using public funds responsibly in both local and national politics.

My focus on this question of standards for state-building began after the American-led invasion of Iraq in 2003. I opposed that invasion, but I accepted the importance of the question of what America needed to do thereafter to fulfill its promise to rebuild an independent democratic Iraq. We need not have any illusions about an "invasion to bring democracy" being good for people in an invaded country. But nations have been and will be invaded for other reasons, as when American forces entered Afghanistan after its Taliban government sponsored a terrorist attack on New York City. Thereafter, promises to help build a new democratic government in the invaded nation should be encouraged. Such promises should not be used to disguise imperialist domination, however, and we cannot hold such promises to account unless we can identify what are the appropriate policies to maximize the chances for successful democratic development.

\section{Theoretical perspectives}

One argument against trying to define any general standards for democratic state-building is that every nation is different, that there is no "cookie-cutter" or "one-size-fits-all" plan for political development. But the real experts on any nation's political culture are its politically active citizens, and they are not neutral observers, as they have a vested interest in maximizing the power of leaders with whom they are connected. In particular, the most prominent indigenous adherents of a state-building intervention may expect to get positions of power at the center of the new regime, and so they could benefit from a constitutional structure that concentrates power in the center. Thus, a state-building mission that relies on their expert political guidance is likely to create an excessively centralized political system, which may alienate local elites in communities that are remote from the capital.

To avoid such biases, international state-building interveners (and the global public to which they are accountable) must rely also on some general principles that are based on an understanding of the common aspects of political systems in all societies. As a social scientist, of course, I have a vested interest in the proposition that there are common general principles 
underlying politics and government in all societies. So I will try here to sketch at least some of these universal principles of politics. Before doing so, I should briefly indicate four strands of the literature in economic theory that have guided my understanding of these principles, but thereafter I will try to support all arguments without any technical analysis.

One strand that has influenced me greatly is Thomas Schelling's (1960) concept of focal points for determining behavior in games with multiple equilibria. (See also Myerson, 2010.) This concept teaches us how, in a broad class of social situations, rational behavior can be influenced by publicly recognized boundaries and standards (such as a charter on state-building).

A second strand is agency theory, which teaches us to appreciate the importance of incentives in organizations. But this theory raises the question of who guarantees that promised incentive rewards will be paid. Agents' incentives in an organization generally depend on higher supervisors reliably judging and rewarding performance. Armen Alchian and Harold Demsetz (1972) argued that the top supervisor's incentive to sustain the system of rewards for agents throughout the organization must depend on his or her ownership of organizational profits. That is, an essential role of top leadership in any organization is to guarantee the organization's systems of incentives for its agents. Agents in a nonpolitical organization could also look to the state's courts for enforcement of contractually promised rewards, but such recourse is not available to agents in a political organization that exists to take state power itself. From this perspective, we may see political leaders as the highest ultimate guarantors of incentive systems in their society.

A third strand is the theory of reputational equilibria in repeated games. In this theory, different kinds of relationships among individuals correspond to different equilibria of repeated games, and individuals become motivated to maintain certain standards of behavior to preserve their good relationships with others. These models suggest how standards of behavior for recognized leaders become the fundamental laws that leaders must uphold to maintain their recognized status as leaders. (For a technical model of how such effects can become the foundations of the constitutional state, see Myerson, 2008.)

A fourth strand is the theory of barriers to entry against new competitors, which can determine how competitive a market system actually is. This theory suggests that the actual competitiveness of a democratic political system will depend on having lower barriers to entry into political competition. This perspective suggests the vital importance of local politics, which 
in a healthy democratic system regularly becomes a path for new candidates to enter national political competition. (See Myerson 2006 for a game-theoretical model of this effect.)

From these conceptual perspectives, we may derive a general theory of political development on that is focused on the essential role of leadership (Myerson, 2011). People in all societies rely on recognized local and national leaders to coordinate the enforcement of laws and the provision of public services, and individuals who hold such positions of leadership are able to distribute rewards and privileges of power. All societies have ways of identifying who can be such a leader. The attributes and achievements that would qualify or disqualify someone for leadership may be different in different societies. But in any society, whenever there is competition for leadership, successful candidates will need active support from many individuals in the society. To motivate such supporters, a successful leader needs a reputation for reliably rewarding loyal supporters. Indeed, the key essential attribute of successful leaders in all societies may be gratitude, as was argued in antiquity by Xenophon, the ancient Greek philosopher who gave economics its name (see Myerson, 2009). People would flock to offer their support to such a person who is viewed as a likely future leader of their community, in hopes of enjoying benefits of the leader's future patronage.

On the other hand, an individual who is not considered a serious contender for leadership would be unable to get support, regardless of his or her personal qualities, as nobody would waste much effort on supporting a candidate who is regarded as having no chance of winning. So questions of political leadership in any society have the nature of a coordination game, in which everyone wants to get credit for supporting the leader whom everyone else will support. Such coordination games have multiple equilibria, and anything that focuses people's attention on any particular equilibrium can make it the rational outcome, as a self-fulfilling prophecy according to Schelling's (1960) focal-point effect. Thus, anything in the culture or history of a society that makes people begin to regard one qualified individual as likely to be a powerful leader can motivate rational political behavior that would indeed make this individual a powerful leader.

This theoretical perspective helps us to see how the generally recognized distribution of power tends to be self-reinforcing and self-perpetuating in a society. As a result, even a shortterm foreign intervention in a nation's political system can have very long-term political consequences, unless the population generally rejects the legitimacy of the foreign intervention. 
Any society's norms for identifying its authoritative leaders are its core cultural asset, the key to its autonomous existence. That is why foreign political interference can be so dangerous. But the norms for identifying qualified political leaders may also become dysfunctional, as when violent attacks on opponents are accepted as normal behavior of political leaders. When a consensus about lawful national leadership cannot be found and political violence becomes chronic, then a foreign state-building intervention might seem potentially beneficial.

\section{Some practical questions of state-building}

It might seem easy to prove the benign non-imperialist nature of an intervention simply by holding elections under a popularly ratified constitution. However, there are plausible scenarios in which democratic formalities could be a cover for the installation of a government handpicked by the foreign interveners.

When foreign forces have pacified a nation, they must be involved in establishing a transitional administration to supervise the reconstruction of the nation's political system. The interim leader of this transitional administration will need the approval of the foreign interveners; and, with their approval, this leader will be able to get his (or her) supporters strongly represented in the commissions that will draft a new constitution and supervise new elections. These supporters, expecting that their leader is likely to win the first election, could use their influence in the constitutional commission to write a draft constitution that specifies a centralized government under a strong president. Voters who are given a choice only between this draft constitution and an unspecified alternative of chaos are likely to ratify the constitution. Then the established "interim" leader, having exclusive control of government patronage and overseeing the electoral process, will be well positioned to win subsequent presidential elections against any rivals. Indeed, many of the most prominent potential rivals may decide that they can improve their chances of political advancement by joining the established leader's coalition, rather than trying to compete against him. Thus, even with a formally democratic process of plebiscites and elections, the long-term political future of a nation could become dominated by a leader whose owes his position more to foreign interveners than to domestic popular approval.

The hypothetical scenario sketched above may resemble the sequence of events in recent state-building interventions, but I am not trying to portray any existing regime as a puppet of foreign powers. My point is that foreign state-building interveners need to do more than just 
hold elections if they want to credibly assure the world they are building a state that is truly independent and democratic, with a political leadership that is truly determined by competition for domestic popular approval.

One important point about the establishment of the Karzai regime in Afghanistan is that, although the United States led the military intervention that drove out the Taliban, the subsequent process of political reconstruction in Afghanistan had broad international supervision from other nations and from the United Nations Secretary-General. Such multi-national political oversight can provide an important way of certifying that the foreign military interveners are sincerely aiming to build an independent state, not an imperialist puppet.

Now consider also the process of writing a constitution. It is not difficult to make sure that various political factions have some representation on a constitution-writing commission. But if the commission is to get anything done, one faction is likely play a leading role in its work, and most likely this dominant faction will be allied with the leader of the transitional government. This dominant faction will then have enormous power to determine the nation's future political rules, if no alternative to political chaos can be presented to the public without their approval. But we should ask, why must a constitutional commission report only one draft constitution? There is no fundamental reason why the leading authors of a democratic constitution should exercise their power without any democratic competition. An alternative procedure could allow any group that includes more than $1 / 3$ of the constitutional commission to publish a draft constitution for popular ratification. Then, unless the dominant faction can win the consensus support of $2 / 3$ of the constitutional commission, the public could be given a democratic competitive choice among two alternative draft constitutions in the vote for ratification. (The 1/3 threshold would guarantee that the commission could report at most two alternatives for the public to choose among. If the option of "vote for neither" is allowed in the ratification vote, then a return to a new commission would be required only if neither draft won a majority vote.)

Even in cases where the commission ultimately reached a consensus to report only one constitution, the ability of a minority in the commission to offer the public a separate alternative could allow more balanced negotiations within the commission. So a dominant faction would generally prefer to not admit any possibility of a minority issuing a competitive constitutional proposal. But this competitive possibility could be reasonably prescribed by chartered standards 
for foreign state-building interveners who, as they oversee the establishment of a constitutionwriting commission in an occupied nation, need to credibly demonstrate their commitment to building a truly democratic state.

The question of control over the process of drafting a new constitution is, however, only a small part of the fundamental dilemma that confronts foreign interveners who promise to build an independent state in an occupied nation. The critical core of this dilemma comes in assigning authority for the transitional government. Whoever gets control of the interim transitional government will have power to distribute patronage and build a network of supporters throughout the nation. But a national political vacuum typically exists after a state-building intervention, as the foreigners intervened either to destroy an internationally unacceptable political system or to end an anarchic breakdown of the state. In this political vacuum, the interim leader's ability to build the first national patronage network after the intervention can become a decisive advantage over all potential rivals. Thus, in handing "interim" transitional authority to one leader, the foreign interveners may be effectively choosing the long-term leader of the nation.

One way for foreign interveners to avoid selecting an interim leader for the occupied nation is by retaining direct foreign control over the government in the transitional period, as the United States did in appointing L. Paul Bremer to head the Coalition Provisional Authority in Iraq after the invasion of 2003. Obviously this approach fails to solve the problem of reducing foreign political influence, which it merely makes overt instead of covert.

There are, however, at least two important ways for foreign interveners to pass political authority in the transitional government back to indigenous leaders without placing overall authority in the hands of any one top leader. First, substantial authority in the transitional government could be devolved to locally elected councils, to avoid giving all authority to one national leader. Second, the national administrative authority that cannot be decentralized could be assigned to a broadly representative national assembly which has the power to select the leading national ministers, and to replace them at any time, under a standard parliamentary system. In fact, the government of the United States of America during its revolutionary transition to independence was characterized by both of these principles of decentralization and parliamentary responsibility, under the Articles of Confederation that applied from 1776 to 1788. Recent American state-building interventions have cultivated more centralized regimes, 
however.

Successful democracy depends on vital interactions between local and national politics. To understand why, we need to think more carefully about the nature of democracy as a competitive system. Even with free elections, a corrupt political party could maintain a grip on power if the voters believed that other parties' candidates would not be any better. Thus, a successful democracy requires more than just elections; it requires alternative candidates who have good democratic reputations for using power responsibly to benefit the public at large, not merely to reward a small circle of supporters.

A record of using public resources responsibly in local government can qualify a local leader to become a competitive candidate for power at higher levels of government. Thus, local democracy can help to make national democracy more competitive. In effect, local democracy can reduce barriers against entry into national democratic competition.

Conversely, national political parties can also help to make local democracy more competitive by sponsoring alternative candidates in local elections. Local political bosses should know that, if they lose popular support, they could face serious challengers supported by a rival national party. From the first organizational meetings, local elections should involve representatives from two or more parties that have made a commitment to democracy. Such political parties develop naturally in a national assembly. Once a national assembly has been selected, a good rule is that any party that is endorsed by at least some minimal fraction of the national assembly should be able to participate in all elections, both in nominating candidates and in monitoring electoral processes.

We should note, however, that the formation of a majority coalition to choose a prime minister was a long and difficult process in Iraq's new parliamentary government after 2004. This difficulty can be readily understood if we recognize that, in a nation with no recent history of democratic constitutional government, there are not likely to be any political leaders with proven records of reliably maintaining constitutional power-sharing agreements with coalition partners. In an authoritarian political system, the common expectation is that any top leader will concentrate power in the hands of his or her own network of loyal supporters. So it is not surprising that efforts to build a coalition for the first transitional government may require some active encouragement by foreign interveners, as when the United States guided the selections of Hamid Karzai and Iyad Allawi to lead the first post-intervention governments in Afghanistan 
(2002) and Iraq (2004). But this external influence can be mitigated if the foreign interveners support the right of a majority in the national assembly to name a new national leader at any time thereafter, according to a parliamentary rule with constructive no-confidence votes.

Other important pillars of a new state include its security forces and its administrative agencies. The development of professional military and police forces is a major focus of the Counterinsurgency Field Manual (2007), and the development of professional staff for a finance ministry that can reliably control the expenditure of government funds has been emphasized by Ashraf Ghani and Clare Lockhart (2008). But incentives in such units and agencies ultimately depend on political leadership. If political leaders do not support the standards for evaluating and rewarding the service of professionals in public service then these standards cannot be maintained. Local political leaders have a vital role in the oversight of local police. Thus, in answer to our original question of what comes first in building a successful democratic society, political development should be seen as the essential first priority that is fundamental to everything else in national reconstruction.

I have argued that the key to democratic political development is to increase the nation's supply of leaders with good reputations for using public funds to provide public services. The value of new roads and schools should not count more than this political end. When the primary goal is political reconstruction, the essential measure of success for any economic development project is how it enhances the reputations of the political leaders who spend the project's funds. So all public services and development projects should be directed by indigenous political leaders, but they should include both national and autonomous local leaders. To cultivate political leadership at all levels, foreign assistance should be distributed among national and

local governments. Transparent public accounting should be required for all public spending, both by foreign donors and by the national finance ministry, to ensure that the people of this nation can learn what their leaders have spent and what this spending has achieved.

\section{Conclusions}

Questions of how to help a nation develop a strong democratic political system require us to develop a deeper understanding of political systems in general and of democracy in particular. Under any political system, power is held by leaders who organize political networks or parties by promising their supporters that loyal service will be well rewarded. In a dictatorship, national 
power is exercised by one leader's political network, which tolerates no rival. In democracy, different leaders with rival political networks must compete for voters' approval as the key to power. Effective democratic competition requires that voters should be able to identify two or more qualified candidates with good reputations for each elective office.

Thus, to build democracy in a transitional period of foreign intervention, it must be a time when new forms of democratic political leadership develop in the nation. The intervening powers in this transitional period should do what they can to create opportunities for local leaders to develop reputations for spending public funds responsibly, and for national leaders to develop reputations for working constructively with autonomously elected local officials and with leaders of other factions in the national assembly. These reputations will be the essential long-term basis of democracy in this nation.

From this perspective, we have suggested a number of basic principles that could be included in a charter or standard plan for democratic state-building. As a game theorist, I understand that the specific rules of the game may matter, so let me summarize these suggestions as a very specific standard template that could be applied in any such intervention. First, with the broadest possible multinational political supervision, the intervening powers could sponsor a broadly representative interim national assembly. Then, with the participation of parties that are represented in this interim assembly, local elections could be held to choose local councils in districts throughout the nation. Once these local councils are in place, the transitional national assembly could be reconstituted to include representatives of these local councils (as was done in the American Revolution under the transitional Articles of Confederation). National executive authority in the transitional period could be held by a prime minister and cabinet with parliamentary responsibility to the national assembly. In the commission that is formed to write a permanent constitution, a minority with more than $1 / 3$ of the commission could be allowed to report an alternative draft constitution to be considered by the nation for ratification. Throughout this transitional period, foreign assistance could be distributed to both the national executive authority and the local councils, to broadly distribute opportunities for local and national leaders to demonstrate their abilities to spend public funds responsibly. Foreign donors should work with the national finance ministry to give the people of this nation a full transparent accounting of the assistance funds that their leaders have gotten to spend at all levels of government.

Our search for principles to guide democratic state-building after an international military 
intervention has been undertaken, not to justify such interventions, but to mitigate their consequences. Foreign interveners who have militarily occupied part or all of a nation inevitably have enormous ability to harm and some ability to help the people of the occupied nation. The goal here has been to understand how they might best try to help foster the development of strong democratic foundations for the restored state.

\section{References}

Armen A. Alchian and Harold Demsetz, "Production, information costs, and economic organization," American Economic Review 62:777-795 (1972).

Paul Collier, The Bottom Billion (Oxford U. Press, 2007).

James Dobbins, Seth G. Jones, Keith Crane, and Beth Cole DeGrasse, The Beginner's Guide to Nation-Building (RAND, 2007).

Ashraf Ghani and Clare Lockhart, Fixing Failed States (Oxford, 2008).

Roger Myerson "Federalism and incentives for success of democracy," Quarterly Journal of Political Science 1:3-23 (2006).

Roger Myerson, "The autocrat's credibility problem and foundations of the constitutional state," American Political Science Review 102:125-139 (2008).

Roger Myerson, "A field manual for the cradle of civilization: theory of leadership and lessons of Iraq," Journal of Conflict Resolution 53(3):470-482 (2009).

Roger Myerson, "Learning from Schelling's 'Strategy of Conflict'," Journal of Economic Literature 47(4):1109-1125 (2010).

Roger Myerson, "Toward a theory of leadership and state-building," Proceedings of the National Academy of Sciences U.S.A. 108(supplement 4):21297-21301 (2011).

Thomas C. Schelling, The Strategy of Conflict (Harvard U. Press, 1960).

U.S. Army and Marine Corps, Counterinsurgency Field Manual FM 3-24 (U. Chicago Press, 2007).

Xenophon, The Education of Cyrus, translated by Wayne Ambler (Cornell U. Press, 2001).

AUTHOR'S ADDRESS: Roger Myerson, Economics dept, U. of Chicago, 1126 East 59th Street, Chicago, IL 60637. Phone: +1-773-834-9071. Email: myerson@uchicago.edu. Web site: http://home.uchicago.edu/ rmyerson/ This paper has been written for inclusion in Economics for the Curious, edited by Robert Solow and Janice Murray. Pre-print versions of this paper are available at http://home.uchicago.edu/ rmyerson/research/std4sb.pdf [Current version: Apr 23, 2014] 